\title{
シグナル開始と終結の分子機構——CSK 導入細胞の解析
}

\author{
鈴 木 毅・廣 瀬 直人 \\ 名田茂之*・本田善一郎・伊藤 幸治
}

Jpn. J. Clin. Immun., 19 (6) : 568〜568, 1996.

\section{I. 目的}

src 型チロシンキナーゼ lyn は高親和性 IgE 受容体 (FceRI) やインテグリンを介するシグナル质達に関 与すると考えられているが focal adhesion kinase (FAK) との関連など不明な点も多い. 我々は, src 調節領域のチロシンをリン酸化してキナーゼ活性を抑 制する CSK の強制導入を手法として， src の役割を 検索した.

\section{II. 方 法}

ラット肥満細胞株 RBL に CSK, 膜結合型 CSK $(\mathrm{mCSK})$, キナーゼ久損体 $(\mathrm{mCSK}(-))$ を高発現 し, FceRI を介する細胞内シグナル及びヒスタミン 分泌を検討した.インテグリン刺激として fibronectin（FN）への接着を用い, 細胞内蛋白のリン 酸化及び遊走を検討した.

\section{III. 結 果}

lyn の比活性は CSK, 更に mCSKによって強く抑
制された. $\operatorname{mCSK}(-)$ (優勢抑制変異体) によって lynの比活性は著しく上昇した. F c $\varepsilon$ RI 架橋による lyn の活性化一分泌反応は CSK, mCSKによって遅延 した. $\mathrm{mCSK}(-)$ は反応の潜時は変えずに反応終結を 極めて強く遅延した.FN 接着刺激で観察される 70 $\mathrm{kD}$ (paxillin), $120 \mathrm{kD}$ 付近の蛋白のリン酸化もやは り CSK, さらに mCSKによって遅延した，FNに対 する遊走能は CSK 発現細胞, $\mathrm{mCSK}$ 発現細胞で顕著 に低下していた。

\section{IV. 結 語}

CSK はおそらくフォスファターゼとのバランスに おいて Fc $\varepsilon$ RI 架橋による Iynの活性化の開始とその 終結を調節していると考えられる。また CSK はイン テグリンを介したシグナル伝達に関与し，細胞の接 着, 移動をダイナミックに調節していることが推測さ れる. 